\title{
URGENSI KOMPETENSI PEDAGOGIK GURU VOKASIONAL PADA PEMBELAJARAN ABAD 21
}

\author{
Bonita Destiana \& Pipit Utami \\ Universitas Negeri Yogyakarta \\ e-mail: bonita@uny.ac.id
}

\begin{abstract}
This article describes the pedagogical competence, development issues and development learning needs related to the preparation ofTAV vocational teachers in the 21 st century. Data were taken using survey methods. The results of the study show that pedagogical competence of TAV vocational teachers in the 21st century are very important. Nine aspects of pedagogic competence that most importantare: (1) competencybased learning; (2) the use of vocational learning models; (3) preparing RPP; (4) understanding of vocational educational foundation; (5) understanding the characteristics of learners; (6) preparing assessment instruments; (7) using contextual learning media; (8) utilization of ICT in learning; and (9) material delivery. Various obstacles to the development of pedagogic competence, namely: lack of pedagogik insights, limitations of infrastructure, lack of ICT usage updates, and burdened with additional tasks. The acquisition of pedagogic competence insights is largely gained by teachers at work. It shows that pedagogical competence development in lectures needs more effort, especially for the competence of vocational concepts, the characteristics of learners and vocational learning in the 21 st century.
\end{abstract}

Keywords:pedagogic competence, vocational teacher, vocational school, 21 st century learning

\begin{abstract}
ABSTRAK
Artikel ini memaparkan kompetensi pedagogik, permasalahan-permasalahan pengembangan dan kebutuhan pengembangan pembelajaran terkait penyiapan guru vokasional TAV abad 21. Data diambil menggunakan metode survey. Hasil studi menunjukkan bahwa kompetensi pedagogik guru vokasional TAV abad 21 dinilai sangat penting. Sembilan aspek kompetensi pedagogik terpenting, diantaranya: (1) pembelajaran berbasis kompetensi; (2) penggunaan model pembelajaran vokasional; (3) menyusun RPP; (4) pemahaman landasan kependidikan vokasional; (5) pemahaman karakteristik peserta didik; (6) menyusun instrumen penilaian; (7) menggunakan media pembelajaran konstekstual; (8) pemanfaatan TIK dalam pembelajaran; dan (9) penyampaian materi pelajaran secara spesifik. Berbagai kendala pengembangan kompetensi pedagogik, yaitu: kurangnya wawasan pedagogik, terbatasnya sarana-prasarana, kurangnya update penggunaan TIK, dan terbebani tugas tambahan. Pemerolehan wawasan kompetensi pedagogik sebagian besar diperoleh guru saat bekerja. Hal tersebut menunjukkan bahwa pengembangan kompetensi pedagogik di perkuliahan perlu lebih diupayakan, khususnya untuk kompetensi Konsep pendidikan vokasional, Karakteristik peserta didik dan Pembelajaran vokasional di abad 21.
\end{abstract}

Kata Kunci: kompetensi pedagogik, guru vokasional, SMK, pembelajaran abad ke-21

\section{PENDAHULUAN}

UU No. 14 tentang Guru dan Dosen menyebutkan bahwa kompetensi guru meliputi kompetensi pedagogik, kepribadian, sosial, dan profesional (Republik, 2005). Apabila dikaitkan dengan perubahan signifikan pada abad 21 terkait perkembangan teknologi dan perubahan kebutuhan dunia kerja, maka penguasaan teknologi merupakan kompetensi yang mutlak harus dikuasai seorang guru vokasional ideal (P21 CL, 2015). Dilain pihak, meskipun teknologi menjadi hal penting, tetapi kualitas guru sebagai SDM (Sumber Daya Manusia) yang bertanggungjawab di "garis depan" pembelajaran merupakan hal yang 
utama, dalam hal ini guru harus memiliki kompetensi pedagogik. Tanpa mengabaikan kompetensi-kompetensi lainnya, artikel ini difokuskan pada kompetensi pedagogik. Kompetensi pedagogik merupakan kemampuan guru dalam pengelolaan pembelajaran peserta didik. Kompetensi guru dapat dikembangkan melalui pembelajaran pada program S1 kependidikan di LPTK. Akan tetapi tidak semua guru adalah lulusan LPTK. Oleh karena itu, Pendidikan Profesi Guru (PPG) bagi lulusan S1 nonkependidikan dititikberatkan pada pengembangan kompetensi pedagogik (Republik, 2008). Hal tersebut menunjukkan urgensi pengembangan kompetensi pedagogik bagi seorang guru. Guru memiliki tugas utama dalam hal pendidikan, sehingga penguasaan kompetensi pedagogik merupakan kompetensi yang harus dikuasai guru.

Pengamat pendidikan dan Dosen

Universitas Paramadina, Mohammad Abduhzen (Margaret, 2014) menyatakan bahwa kompetensi pedagogik guru masih rendah. Lebih lanjut lagi dari hasil UKG tahun 2015, Direktur Jenderal Guru dan Tenaga Kependidikan (GTK) Kemendikbud, Sumarna Suraparanata menyatakan bahwa rata-rata nasional hasil UKG untuk kompetensi pedagogik adalah 48,94. Nilai tersebut berada di bawah standar kompetensi minimal (SKM), yaitu 55. Rata-rata hasil UKG untuk kompetensi pedagogik Provinsi Daerah Istimewa Yogyakarta adalah 56,91(Desliana, 2016). Nilai rata-rata tersebut sedikit diatas SKM, akan tetapi nilai tersebut menunjukkan bahwa guru-guru di DIY belum menguasai kompetensi pedagogik secara komprehensif. Djoko (2014: 151-152), menyatakan bahwa penguasaan aspek-aspek kompetensi pedagogik para guru SMK KK-TAV di Yogyakarta, Sleman dan Kulonprogo memprihatinkan. Untuk menindaklanjuti hasil penelitian tersebut, maka perlu diketahui derajat kepentingan dari aspek-aspek pada kompetensi pedagogik. Perolehan derajat kepentingan akan dapat digunakan untuk mengetahui prioritas pengembangan aspek kompetensi pedagogik bagi guru SMK KK TAV.

Kompetensi pedagogik tersebut sekurang-kurangnya meliputi: pemahaman wawasan atau landasan kependidikan, pemahaman terhadap karakteristik peserta didik dari aspek fisik, moral, spiritual, sosial, kultural, emosional, dan intelektual; penguasaan teori belajar dan prinsip-prinsip pembelajaran yang mendidik; pengembangan kurikulum atau silabus terkait mata pelajaran yang diampu; perancangan pembelajaran; pelaksanaan pembelajaran yang mendidik dan dialogis; pemanfaatan teknologi informasi dan komunikasi untuk kepentingan pembelajaran; pengembangan peserta didik untuk mengaktualisasikan berbagai potensi yang dimilikinya; berkomunikasi secara efektif, empatik, dan santun dengan peserta didik penilaian dan evaluasi hasil belajar; pemanfaatan hasil penilaian dan evaluasi untuk kepentingan pembelajaran; dan tindakan reflektif untuk peningkatan kualitas pembelajaran (Republik, 2005: 6, 2007, 2008, 2009a, 2009b, 2010a dan 2010b).

Pada partnership for 21 st century learning terdapat tiga keterampilan yang perlu dikembangkan dalam pembelajaran. Keterampilan tersebut adalah: (1) learning and innovation skills; (2) information, media and technology skills; dan (3) life and career skills. Guru vokasional abad 21 harus mempelajari ketiga keterampilan tersebut selama menjadi mahasiswa. Dengan demikian saat menjadi guru, mereka akan mampu mengembangkan keterampilan yang sama (membelajarkan) kepada peserta didiknya. Oleh karena itu kompetensi pedagogik guru vokasional abad 21

Unsur-unsur kompetensi pedagogik menurut Claire Rees, et.al. (2007) diantaranya: memahami pengetahuan dan hasil penelitian terkait pembelajaran; memahami perbedaan karakteristik dalam pembelajaran; memahami sistem pendidikan; memahami interaksi dalam dunia pendidikan; menganalisis dan mengembangkan kemampuan belajar; memiliki ide-ide baru terkait globalisasi dalam sistem 
pendidikan; memahami konsep dan teori yang ditemui saat belajar; dan menggunakan TIK. Kualifikasi kejuruan yang terkait dengan kompetensi pedagogik menurut International Labour Organization (ILO) (2010: 19) terdiri dari: pengetahuan mendalam dari beberapa materi pembelajaran; kemampuan TIK; pemahaman komprehensif dan kemampuan untuk berbagi fakta-fakta ekonomi dan sosial kepada siswa; kemampuan menanamkan keterampilan dasar belajar kepada siswa; meneliti, melakukan refleksi dan melakukan perubahan yang diperlukan dalam praktik pengajaran; mampu berkomunikasi dan memiliki empati kepada siswa; serta kemampuan untuk berinovasi dan menanamkan inovasi dalam pembelajaran.

Standar kualifikasi guru Technical and Vocational Education and Training (TVET) terkait kompetensi pedagogik menurut Peter Gerds \& Zhi-Qun Zhao (2006: 131) adalah: merencanakan, melaksanakan dan mengevaluasi pembelajaran; menyediakan lingkungan belajar, materi dan media yang terkait dunia kerja; penilaian; bimbingan siswa; dan pengembangan dan evaluasi kurikulum. Terkait kompetensi pedagogik, Harry Stolte (2006: 28-29) menyatakan bahwa guru TVET seharusnya berkualitas dalam mengajar dan mampu menggunakan TIK dalam pembelajaran. Felix Rauner \& Joachim Dittrich (2006: 39-40) menyatakan bahwa salah satu area tanggungjawab guru TVET yang harus disiapkan selama kuliah di perguruan tinggi adalah analisis, desain dan evaluasi pembelajaran. Joachim Dittrich (2006:112-114) memaparkan bahwa area-area kompetensi guru TVET terkait kompetensi pedagogik adalah mampu melaksanakan dan mengembangkan pembelajaran terkait dunia kerja. Kompetensi pedagogik menurut Qiding Yu (2009: 63-64) adalah menguasai bidang pengajaran meliputi kode etik; hubungan industri, desain kurikulum; pengajaran dan pembelajaran; penilaian; dan bimbingan vokasional kepada siswa. Fritz Oser, Patrizia Salzmann, \& Sarah Heinzer (2009: 65-83) menyatakan bahwa terdapat salah satu kelompok dimensi untuk mengukur kualitas kompetensi guru vokasional adalah aspek kualitas pengajaran.

Dari berbagai profil-profil guru vokasional tersebut, secara umum dapat disimpulkan bahwa profil kompetensi pedagogik guru vokasional yang berkualitas, meliputi: (1) pemahaman mengenai konsep pendidikan vokasional; (2) memahami karakteristik peserta didik; dan (3) memiliki kemampuan mengelola pembelajaran, khususnya terkait pengembangan keterampilan berfikir, keterampilan bekerja dan penggunaan teknologi di abad 21.

Tuntutan sebagai guru vokasional adalah perlu memahami esensi dari hakikat pendidikan vokasional yaitu sebagai pendidikan yang mempersiapkan lulusannya siap kerja. Guru vokasional berkualitas perlu membekali dirinya dengan konsep pendidikan vokasional tersebut, agar peserta didiknya juga memiliki kesiapan kerja sesuai kebutuhan dunia kerja dengan bidang yang dikuasai. Terdapat 16 teori pendidikan vokasional menurut Prosser (Wardiman, 1998: 38-39), dimana salah satunya terkait lingkungan pembelajaran yang harus berupaya melatih dan membiasakan peserta didik berperilaku seperti di dunia kerja. Mahasiswa calon guru vokasional harus dilatih dan dibiasakan sebagai seorang guru vokasional mulai dari di perkuliahan. Ada dua hal yang perlu ditekankan dalam upaya penyiapan guru di Lembaga Pendidikan Tenaga KependidikanPendidikan Teknologi dan Kejuruan (LPTKPTK), yaitu proses perkuliahan di LPTK diupayakan untuk melahirkan calon guru yang mampu mengeksplorasi potensi tiap siswanya dan responsif terhadap perkembangan IPTEK. Terkait hal pertama, maka penguasaan kompetensi pedagogik harus dikuasai oleh mahasiswa Prodi Pendidikan Teknik Elektronika (PTE) sebagai calon guru vokasional TAV.

Berdasarkan berbagai permasalahan yang telah dipaparkan, khususnya terkait hasil UKG bidang pedagogik yang menunjukkan 
bahwa guru-guru di DIY belum menguasai kompetensi pedagogik secara komprehensif, maka perlu diketahui tingkat kesadaran atau pemahaman guru terhadap pentingnya penguasaan kompetensi pedagogik. Pemahaman dan kesadaran tentang pentingnya penguasaan kompetensi pedagogik tentu akan bermanfaat bagi para guru SMK agar responsif dan adaptif terhadap perubahan di abad 21. Sedangkan dampak jangka panjang dari penyiapan kompetensi pedagogik guru vokasional secara komprehensif adalah diperolehnya lulusan SMK yang siap, responsif dan adaptif dengan dunia kerja. Dengan demikian dapat dikatakan bahwa derajat kepentingan penguasaan kompetensi pedagogik bagi guru vokasional memiliki urgensitas yang tinggi.

Selain derajat kepentingan tersebut, perlu juga diketahui permasalahan dan kebutuhan guru SMK KK-TAV dalam mengembangkan kompetensi pedagogik. Dengan diketahui hal-hal tersebut, maka dapat dirumuskan solusi penyelesaian dan upayaupaya yang dapat dilakukan untuk mengembangkan kompetensi pedagogik.

\section{METODE}

Pada penelitian ini data diperoleh dari kuesioner yang berisi pernyatan tertutup, pertanyaan terbuka, komentar dan saran dari para responden terkait dengan kompetensi pedagogik guru vokasional TAV abad 21, permasalahan-permasalahan pengembangan dan kebutuhan pengembangan pembelajaran terkait penyiapan guru vokasional TAV abad 21. Tabel 1 merupakan tahapan pelaksanaan survei untuk analisis kebutuhan dalam penelitian ini.

Tabel 1. Tahapan penelitian dengan mengadopsi McCawley (2009)

\begin{tabular}{|c|c|c|}
\hline No & Langkah & Hasil \\
\hline 1 & $\begin{array}{l}\text { Merumuskan } \\
\text { permasalahan }\end{array}$ & $\begin{array}{l}\text { - Nilai UKG bidang pedagogik yang belum menunjukkan bahwa } \\
\text { guru-guru di DIY belum menguasai kompetensi pedagogik secara } \\
\text { komprehensif } \\
\text { - Penguasaan aspek-aspek kompetensi pedagogik para guru SMK } \\
\text { KK-TAV di Yogyakarta, Sleman dan Kulonprogo memprihatinkan }\end{array}$ \\
\hline 2 & $\begin{array}{l}\text { Menentukan tujuan } \\
\text { survei }\end{array}$ & $\begin{array}{l}\text { Memaparkan aspek terpenting kompetensi pedagogik guru } \\
\text { vokasional abad 21, permasalahan-permasalahan pengembangan } \\
\text { kompetensi pedagogik guru vokasional abad } 21 \text {, dan upaya dosen } \\
\text { dalam pengembangan kompetensi pedagogik guru vokasional abad } \\
21\end{array}$ \\
\hline 3 & $\begin{array}{l}\text { Menepntukan konsep } \\
\text { tujuan dari kajian } \\
\text { literatur }\end{array}$ & $\begin{array}{l}\text { Profil ideal kompetensi pedagogik guru vokasional abad } 21 \text { (terdapat } \\
\text { justifikasi expert) }\end{array}$ \\
\hline 4 & $\begin{array}{l}\text { Menentukan } \\
\text { responden }\end{array}$ & $\begin{array}{l}\text { Guru SMK produktif TAV di DIY, mahasiswa PTE konsentrasi } \\
\text { TAV, Dosen PTE }\end{array}$ \\
\hline 5 & Menyusun kuesioner & $\begin{array}{l}\text { Validasi expert untuk kuesioner berisi pernyataan tertutup dengan } \\
\text { lima pilihan, pertanyaan terbuka, dan komentar/saran umum }\end{array}$ \\
\hline 6 & $\begin{array}{l}\text { Mengumpulkan data di } \\
\text { lapangan }\end{array}$ & $\begin{array}{l}\text { Pengambilan di: SMK KK-TAV se-DIY (guru produktif TAV), Prodi } \\
\text { PTE (mahasiswa konsentrasi AV dan Dosen) }\end{array}$ \\
\hline 7 & $\begin{array}{l}\text { Mengolah dan analisis } \\
\text { data }\end{array}$ & $\begin{array}{l}\text { Analisis terkait derajat kepentingan kompetensi pedagogik guru } \\
\text { vokasionalabad } 21\end{array}$ \\
\hline 8 & $\begin{array}{l}\text { Menindaklanjuti hasil } \\
\text { analisis data }\end{array}$ & $\begin{array}{l}\text { Penentuan lima aspek kompetensi pedagogik terpenting, perumusan } \\
\text { permasalahan pengembangan kompetensi dan perumusan kebutuhan } \\
\text { pengembangan kompetensi }\end{array}$ \\
\hline 9 & $\begin{array}{l}\text { Melaporkan hasil } \\
\text { penelitian }\end{array}$ & $\begin{array}{l}\text { Menyusun simpulan terkait kompetensi pedagogik guru vokasional } \\
\text { abad } 21 \text { dan kebutuhan pengembangan pembelajaran terkait } \\
\text { penyiapan guru vokasional TAV abad } 21\end{array}$ \\
\hline
\end{tabular}


Penelitian bertempat di 18 SMK KKTAV di DIY dan Prodi PTE FT UNY. Populasi dalam penelitian ini adalah: (1) 21 SMK KKTAV; (2) 15 mahasiswa PTE konsentrasi Audio Video (AV) angkatan 2014; dan (3) 33 Dosen PTE. Sampel penelitian dipilih terdiri dari: (1) 18 SMK yang dipilih berdasarkan keterwakilan tiap Kabupaten di DIY dan keterwakilan instansi negeri dan swasta; (2) 15 mahasiswa PTE konsentrasi AV; dan (3) 2 Dosen PTE dengan pertimbangan keterwakilan unsur ahli pendidikan vokasional dan ahli bidang Audio Video.
Teknik pengumpulan data yang dilakukan pada saat perumusan masalah adalah studi literatur, wawancara dan observasi. Kuesioner digunakan untuk menjaring tanggapan atas pernyataan tertutup, pertanyaan terbuka dan komentar/saran umum dari para responden. Kuesioner digunakan untuk mengetahui derajat kepentingan kompetensi pedagogik guru vokasional TAV abad 21, permasalahan-permasalahan pengembangan dan kebutuhan pengembangan pembelajaran terkait penyiapan guru vokasional TAV abad 21. Tabel 2 berikut ini merupakan kisi-kisi pernyataan tertutup kuesioner/angket.

Tabel 2. Kisi-kisikuesioner kompetensi pedagogik guru vokasional abad 21

\begin{tabular}{|c|c|c|c|c|c|}
\hline \multirow[b]{2}{*}{ No } & \multirow[b]{2}{*}{ Indikator } & \multirow[b]{2}{*}{ Butir instrumen } & \multicolumn{3}{|c|}{ Butir instrumen } \\
\hline & & & Guru & $\begin{array}{c}\text { Mahasis } \\
\text { wa }\end{array}$ & Dosen \\
\hline 1 & $\begin{array}{l}\text { Konsep } \\
\text { pendidikan } \\
\text { vokasional }\end{array}$ & $\begin{array}{l}\text { - Konsep pendidikan vokasional } \\
\text { - Teori dan prinsip pembelajaran } \\
\text { vokasional } \\
\text { - Outcame lulusan pendidikan } \\
\text { vokasional }\end{array}$ & $1,2,3,4$ & $1,2,3,4$ & $1,2,3,4$ \\
\hline \multirow[t]{2}{*}{2} & Karakteristik & - Pemahaman karakteristik peserta didik & 5,6 & 5,6 & 5,6 \\
\hline & peserta didik & - Pengembangan potensi & 7 & 7 & 7 \\
\hline \multirow[t]{7}{*}{3} & Pembelajaran & - Kurikulum, Silabus & 8,9 & 8 & 8 \\
\hline & & - Media pembelajaran & 10 & 9 & 9 \\
\hline & & - Penilaian & $11-18$ & $10-12$ & $10-12$ \\
\hline & & - Perancangan pembelajaran & 19 & 13 & 13 \\
\hline & & - Model-model pembelajaran & $20-23$ & 14 & 14 \\
\hline & & - Pelaksanaan pembelajaran & $24-29$ & $15-18$ & $15-18$ \\
\hline & & - Penggunaan TIK dalam pembelajaran & 30 & 19 & 19 \\
\hline
\end{tabular}

Pertanyaan terbuka untuk tiap responden berbeda. Terdapat lima pertanyaan terbuka untuk guru SMK, diantaranya terkait: (1) penguasaan semua sub-kompetensi pedagogik; (2) kompetensi pedagogik minimal paling penting; (3) kendala yang dialami guru dalam mengembangkan/ melaksanakan kompetensi pedagogik; (4) dukungan dalam pengembangan kompetensi pedagogik; dan (5) sumber perolehan wawasan terkait kompetensi pedagogik. Terdapat dua pertanyaan untuk mahasiswa konsentrasi AV, yaitu terkait:(1) kompetensi pedagogik yang dikembangkan di perkuliahan; dan (2) bagaimana cara pengembangan kompetensi pedagogik yang diharapkan. Terdapat dua pertanyaan untuk Dosen PTE, diantaranya terkait: (1) kendala pembelajaran di prodi PTE untuk menanamkan kompetensi; dan (2) upaya yang dapat dilakukan dosen untuk mengatasi kendalakendala dalam pembelajaran di prodi PTE untuk menanamkan kompetensi. Instrumen penelitian melalui validasi oleh dua orangahli pendidikan vokasional untuk memperoleh validitas isi. Perbaikan instrumen dilakukan terkait penyusunan redaksi pertanyaan pada isian terbuka menggunakan redaksi yang substantif dan ringkas. Expert judgement juga menyatakan bahwa instrumen sudah mencakup seluruh kompetensi yang dibutuhkan di abad 21 
dan dinyatakan layak. Dengan demikian instrumen bisa digunakan untuk perolehan derajat kepentingan kompetensi pedagogik guru vokasional abad 21 secara empirik.

Teknik analisis data hasil dari angket dalampenelitianini menggunakan analisis statistik deskriptif untuk mengetahui pencapaian skor variabel dengan cara membandingkan skor total yang dicapai (empiris) dengan skor total tertinggi yang ditetapkan. Pengambilan data menggunakan angket dengan lima alternatif pilihan jawaban dengan derajat kepentingan yang berbeda (5: sangat penting; 4: penting; 3 : cukup penting; 2 : kurang penting; dan 1: sangat kurang penting).

Untuk mencari skor rata-rata dalam memberikan penilaian terhadap derajat kepentingan kompetensi, digunakan rumus:

$$
\mathrm{X}_{\mathrm{i}}=\frac{\sum \mathrm{x}}{\sum a \mathrm{x} \sum \mathrm{n}}
$$

keterangan :

$$
\begin{aligned}
& \mathrm{Xi} \quad=\text { skor rata-rata } \\
& \sum \mathrm{x} \quad=\text { jumlah skor } \\
& \sum \mathrm{a} \quad=\text { jumlah aspek yang diamati } \\
& \mathrm{n} \quad=\text { jumlah responden }
\end{aligned}
$$

\section{HASIL}

Pemerolehan hasil studi literatur mengenai profil ideal kompetensi pedagogik guru vokasional TAV abad 21 berdasarkan perundang-undangan RI dan profil guru vokasional berbagai negara terdiri dari 30 butir. Butir-butir tersebut, diantaranya: (1) memiliki pemahaman wawasan atau landasan kependidikan vokasional; (2) menguasai teori belajar dan prinsip-prinsip pembelajaran vokasional yang mendidik secara mendalam; (3) memahami model-model pembelajaran yang mendukung terlaksananya pendidikan vokasional; (4) memahami harapan lulusan pendidikan vokasional untuk mengantarkan lulusan siap bekerja, berwirausaha dan atau melanjutkan studi ke perguruan tinggi; (5) memahami karakteristik peserta didik; (6) memperlakukan peserta didik sesuai karakteristiknya; (7) memfasilitasi pengem- bangan potensi peserta didik untuk mengaktualisasikan berbagai potensi yang dimiliki; (8) menyusun kurikulum pembelajaran pada satuan pendidikan berdasarkan konsep pendidikan vokasional; (9) menyusun silabus pembelajaran yang terkait dengan mata pelajaran yang diampu; (10) menyediakan media pembelajaran terkait mata pelajaran yang kontekstual; (11) menyusun penugasan terkait mata pelajaran yang kontekstual dan mengukur tingkat kesulitan pengerjaan tugas; (12) menyusun instrumen penilaian/ alat ukur/ soal sesuai mata pelajaran; (13) menilai dan mengevaluasi proses dan hasil belajar pada mata pelajaran di kelasnya; (14) melaksanakan penilaian yang beraneka ragam; (15) menganalisis hasil penilaian pembelajaran; (16) memberikan umpan balik terhadap tugas; (17) melakukan tindakan reflektif hasil pembelajaran untuk peningkatan kualitas pembelajaran; (18) melaksanakan perbaikan dan pengayaan dengan memanfaatkan hasil penilaian dan evaluasi; (19) menyusun rencana pelaksanaan pembelajaran; (20) menyelenggarakan pembelajaran berbasis kompetensi yang bermutu, mendidik dan dialogis; (21) menyelenggarakan pembelajaran berbasis proyek (project based learning) yang bermutu, mendidik dan dialogis; (22) menyelenggarakan pembelajaran berbasis kerja (work based learning) yang bermutu, mendidik dan dialogis; (23) menyelenggarakan pembelajaran kontekstual (contextual teaching learning) yang bermutu, mendidik dan dialogis; (24) menyampaikan materi pelajaran secara spesifik terkait ketepatan informasi yang diberikan; (25) memberikan tanggapan secara teratur atas jawaban atau kompetensi peserta didik dengan baik; (26) memberikan penjelasan yang komprehensif terkait materi pelajaran; (27) memberikan kegiatan-kegiatan yang memotivasi dan menumbuhkan komitmen peserta didik dalam pembelajaran; (28) mampu mengelola pembelajaran dan beradaptasi terhadap situasi pembelajaran yang dihadapi (apabila tidak sesuai dengan perencanaan pembelajaran); (29) mampu berkomunikasi 
secara efektif, empatik, dan santun dengan peserta didik; dan (30) memanfaatkan teknologi informasi dan komunikasi untuk kepentingan pembelajaran.

Guru SMK yang menjadi responden dalam penelitian ini berjumlah 51 responden. Terdapat total 18 SMK KK-TAV di DIY yang menjadi responden, dengan rincian 9 SMK Negeri dengan 25 responden dan 9 SMK
Swasta dengan 26 responden. Responden yang terlibat terdiri dari Kepala SMK, Ketua Kompetensi Keahlian, Kepala Bengkel, Guru Kelas Produktif, dan Guru Produktif Mata Pelajaran. Dari keterwakilan responden tersebut, diperoleh informasikompetensi pedagogik guru vokasional secara empirik akan bermakna. Tabel 4 berikut menunjukkan persebaran responden Guru SMK.

Tabel 4. Persebaran responden Guru SMK

\begin{tabular}{lllccc}
\hline Wilayah & No. & Nama SMK & Negeri & Swasta & Jumlah \\
\hline Yogyakarta & 1 & SMK 1 Piri Yogyakarta & & $\sqrt{ }$ & 3 \\
& 2 & SMK Muhammadiyah 3 Yogyakarta & & $\sqrt{ }$ & 6 \\
\multirow{5}{*}{ Sleman } & 3 & SMK N 3 Yogyakarta & $\sqrt{ }$ & & 3 \\
& 4 & SMK N 2 Yogyakarta & $\sqrt{ }$ & $\sqrt{ }$ & 1 \\
Bantul & 5 & SMK Muhammadiyah Turi & & $\sqrt{ }$ & 1 \\
& 6 & SMK N 2 Depok & $\sqrt{ }$ & & 5 \\
& 7 & SMK N 1 Pundong & $\sqrt{ }$ & & 5 \\
& 8 & SMK N 1 Dlingo & & $\sqrt{ }$ & 3 \\
Kulon Progo & 9 & SMK Maarif 1 Piyungan & & $\sqrt{ }$ & 1 \\
Gunung Kidul & 12 & SMK Muhammadiyah 1 Temon & & $\sqrt{ }$ & 1 \\
& 13 & SMK Maarif 1 Wates & & $\sqrt{ }$ & 3 \\
& 11 & SMK Muhammadiyah 1 Playen & & $\sqrt{ }$ & 5 \\
& 15 & SMK N 1 Purwosari & $\sqrt{ }$ & & 5 \\
& 16 & SMK N 1 Saptosari & $\sqrt{ }$ & & 1 \\
& 17 & SMK N 1 Tepus & $\sqrt{ }$ & & 3 \\
& 18 & SMK N 3 Wonosari & $\sqrt{ }$ & & 51 \\
\hline
\end{tabular}

Skor untuk kompetensi pedagogik sebesar 4,31 yang termasuk dalam kategori sangat penting. Secara umum kompetensi pedagogik terdiri dari tiga aspek, yaitu konsep

pendidikan vokasional, karakteristik peserta didik dan pembelajaran. Gambar 2 menunjukkan pemerolehan derajat kepentingan dilihat dari tiap butir aspek.

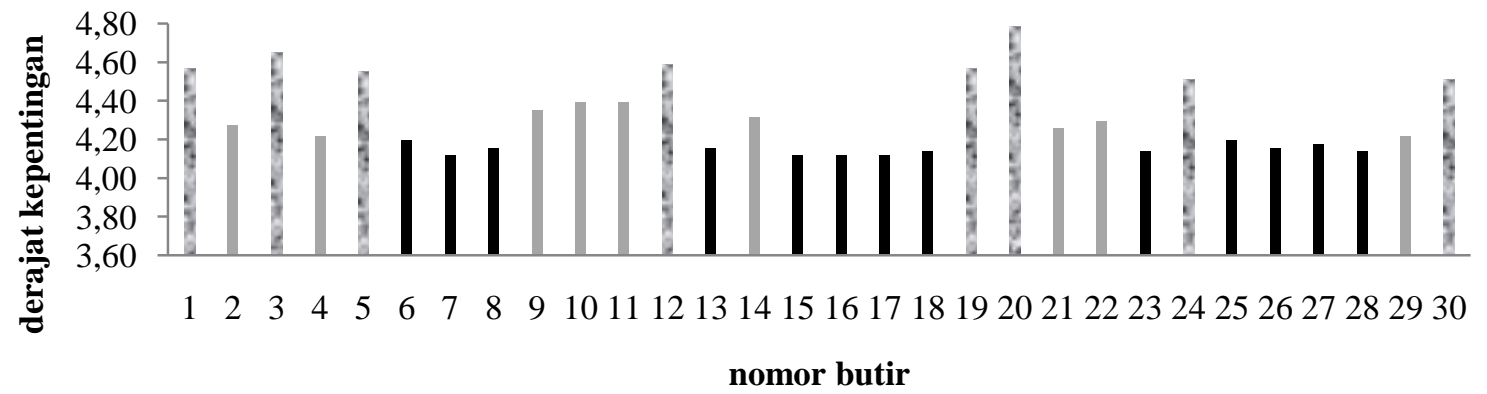

Gambar 2. Derajat kepentingan aspek kompetensi pedagogik menurut guru SMK KK-TAV 
Dilihat dari tiap aspek pada kompetensi pedagogik, dapat diketahui bahwa terdapat 17 butir instrumen yang masuk pada kategori sangat penting. Dari 17 butir tersebut, diambildelapan butir tertinggi yang memiliki skor lebih dari 4,5. Butir-butir tersebut adalah butir 1 skor 4,57 (memiliki pemahaman wawasan atau landasan kependidikan vokasional), butir 3 skor 4,65 (memahami model-model pembelajaran yang mendukung terlaksananya pendidikan vokasional), butir 5 skor 4,55 (memahami karakteristik peserta didik), butir 12 skor 4,59 (menyusun instrumen penilaian/ alat ukur/ soal sesuai mata pelajaran), butir 19 skor 4,57 (menyusun RPP), butir 20 skor 4,78 (menyelenggarakan pembelajaran berbasiskompetensi yang bermutu, mendidik dan dialogis), butir 24 skor 4,51 (menyampaikan materi pelajaran secara spesifik terkait ketepatan informasi yang diberikan), dan butir 30 skor 4,51 (memanfaatkan TIK untuk kepentingan pembelajaran).

Hal tersebut tidak jauh berbeda dengan hasil isian terbuka dari para responden terkait kompetensipedagogik minimal yang perlu dimiliki. Jawaban dari para responden adalah, mampu menyajikan materi yang mudah dipahami siswa dengan berbagai metode, mendampingi siswa yang kesulitan belajar, penguasaan metode pembelajaran, pengembangan media pembelajaran, menyusun RPP, memiliki wawasan vokasional, dan mahir menggunakan TIK. Sedangkan kendala dalam mengimplementasikan kompetensi pedagogik adalah kurangnya pemahaman tentang wawasan kompetensi tersebut. Berdarkan data dari responden guru pemerolehan wawasan saat kuliah S1 dimiliki oleh $28 \%$ responden, sedangkan sisanya $72 \%$ diperoleh saat bekerja.

Butir instrumen untuk mahasiswa PTEAV dan Dosen PTE memiliki perbedaan, tetapi memiliki unsur yang sama. Terdapat 19 butir instrumen. Butir-butir tersebut diantaranya: (1) memiliki pemahaman wawasan atau landasan pendidikan vokasional; (2) menguasai teori belajar dan prinsip-prinsip pembelajaran vokasional yang mendidik; (3) memahami model-model pembelajaran yang mendukung terlaksananya pendidikan vokasional; (4) memahami harapan lulusan pendidikan vokasional; (5) memahami karakteristik peserta didik; (6) memperlakukan peserta didik sesuai karakteristiknya; (7) memfasilitasi pengembangan potensi peserta didik untuk mengaktualisasikan berbagai potensi yang dimiliki; (8) menyusun kurikulum dan silabus pembelajaran yang kontekstual; (9) menyediakan media pembelajaran terkait mata pelajaran yang kontekstual; (10) menyusun instrumen penilaian/ alat ukur/ soal sesuai mata pelajaran secara kontekstual dan mengukur tingkat kesulitan; (11) melaksanakan dan menganalisis penilaian/hasil penilaian yang beraneka ragam; (12) memberikan umpan balik dan melakukan tindakan reflektif (perbaikan dan pengayaan) hasil pembelajaran; (13) menyusun rencana pelaksanaan pembelajaran; (14) menyelenggarakanpembelajaran berbasis kompetensi yang bermutu, mendidik dan dialogis; (15) menyampaikan materi pelajaran secara spesifik terkait ketepatan informasi yang diberikan; (16) memberikan tanggapan dan penjelasan yang komprehensif terkait materi pelajaran; (17) memberikan kegiatan-kegiatan yang memotivasi dan menumbuhkan komitmen peserta didik dalam pembelajaran; (18) mampu berkomunikasi secara efektif, empatik, dan santun dengan peserta didik; dan (19) memanfaatkan teknologi informasi dan komunikasi untuk kepentingan pembelajaran.

Mahasiswa PTE Konsentrasi AV yang menjadi responden dalam penelitian ini berjumlah 15 responden yang telah melakukan observasi kompetensi di SMK yang memiliki KK-TAV, sehingga mengetahui kompetensikompetensi sebagai guru di SMK KK-TAV. Dari karakteristik responden tersebut, dinilai informasikompetensi pedagogik guru vokasional secara empirik akan bermakna.Skor untuk kompetensi pedagogik sebesar 4,21 yang termasuk dalam kategori sangat penting. Gambar 3 menunjukkan pemerolehan derajat kepentingan dilihat dari tiap butir aspek. 


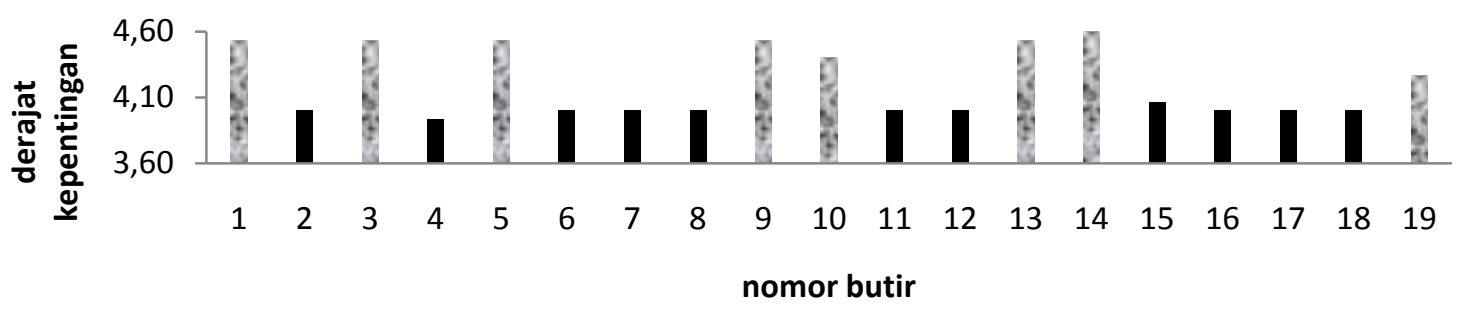

Gambar 3. Derajat kepentingan aspek kompetensi pedagogik menurut mahasiswa PTE-AV

Dilihat dari tiap aspek pada kompetensi pedagogik, dapat diketahui bahwa terdapat 8 butir instrumen yang masuk pada kategori sangat penting. Butir-butir tersebut adalah butir 1 skor 4,53 (memiliki pemahaman wawasan atau landasan kependidikan vokasional), butir 3 skor 4,53 (memahami model-model pembelajaran yang mendukung terlaksananya pendidikan vokasional), butir 5 skor 4,53 (memahami karakteristik peserta didik); butir 9 skor 4,53 (menyediakan media pembelajaran terkait mata pelajaran yang konstekstual), butir 10 skor 4,4 (menyusun instrumen penilaian/ alat ukur/ soal sesuai mata pelajaran secara kontekstual dan mengukur tingkat kesulitan), butir 13 skor 4,53 (menyusun RPP), butir 14 skor 4,60 (menyelenggarakan pembelajaran berbasis kompetensi yang bermutu, mendidik dan dialogis) dan butir 19 skor 4,27 (memanfaatkan TIK untuk kepentingan pembelajaran).

Pemerolehan wawasan kompetensi pedagogik yang diperoleh melalui pembelajaran di S1 oleh mahasiswa diantaranya: memahami karakteristik peserta didik dan pendidikan vokasional, wawasan tersebut masih terbatas, dikarenakan mahasiswa yang menjadi responden adalah mahasiswa semester 4, sehingga mata kuliah kependidikan yang diikutiseperti mata kuliah Pendidikan Sosial Budaya, Ilmu pendidikan,dan Manajemen pendidikan masih terbatas. Mata kuliah kependidikan lainnya diantaranya adalah: Media pembelajaran dan TI, Kurikulum dan Pembelajaran, Psikologi pendidikan, Sosioantropologi pendidikan, Pembelajaran Mikro, Strategi Pembelajaran, Penilaian Pembelajaran, dan Pendidikan Teknologi dan Kejuruan.

Menurut mahasiswa, guru perlu mengetahui dunia vokasional, karena sejatinya seorang calon guru produktif harus mengetahui seluk beluk dari dunia vokasional. Selain itu guru harus bisa menempatkan diri/beradaptasi dengan kondisi setiap kelas karena setiap kelas memiliki peserta didik yang berbeda-beda. Dengan demikian pengembangan kompetensi pedagogik yang diharapkan oleh para mahasiswa adalah pemberian contoh oleh dosen atau penerapan langsung dalam pembelajaran.

Terdapat 2 Dosen PTE yang menjadi responden dengan mempertimbangkan keterwakilan unsur ahli pendidikan vokasional dan ahli bidang Audio Video. Skor rerata yang diperoleh adalah 4,79 yang termasuk dalam kategori sangat penting. Gambar 4 menunjukkan pemerolehan derajat kepentingan dilihat dari tiap butir aspek.

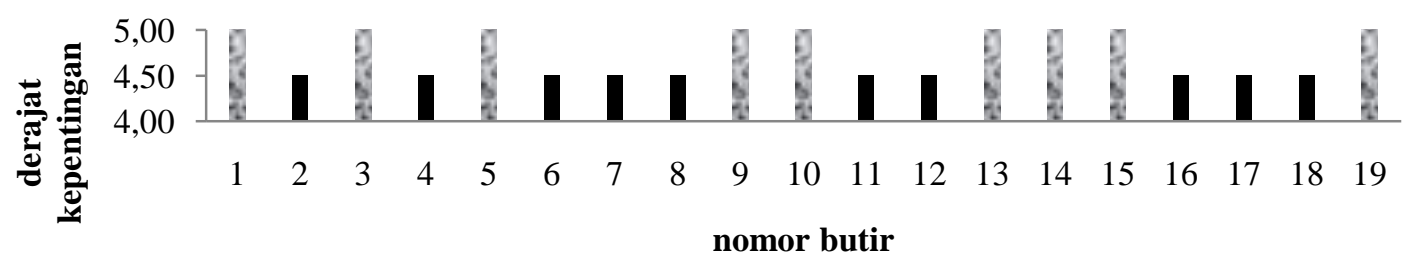

Gambar 4. Derajat kepentingan aspek kompetensi pedagogik menurut Dosen PTE-AV 
Dilihat dari tiap aspek pada kompetensi pedagogik, semua aspek dinilai sangat penting. Aspek yang dinilai dengan skor 5 oleh kedua responden terdapat 9 butir. Butir-butir tersebut adalah butir 1 (memiliki pemahaman wawasan atau landasan pendidikan vokasional), butir 3 (memahami model-model pembelajaran yang mendukung terlaksananya pendidikan vokasional), butir 5 (memahami karakteristik peserta didik), butir 9 (menyediakan media pembelajaran terkait mata pelajaran yang kontekstual), butir 10 (menyusun instrumen penilaian/ alat ukur/ soal sesuai mata pelajaran secara kontekstual dan mengukur tingkat kesulitan), butir 13 (menyusun rencana pelaksanaan pembelajaran), butir 14 (menyelenggarakan berbagai model pembelajaran berbasis kompetensi yang bermutu, mendidik dan dialogis), butir 15 (menyampaikan materi pelajaran secara spesifik terkait ketepatan informasi yang diberikan) dan butir 19 (memanfaatkan teknologi informasi dan komunikasi untuk kepentingan pembelajaran).

Dari ketiga kelompok responden, dapat diketahui bahwa terdapat sembilanaspek kompetensi pedagogik terpenting. Berikut adalah aspek tersebut diurutkan berdasarkan derajat kepentingannya, yaitu: (1) menyelenggarakan pembelajaran berbasis kompetensi yang bermutu, mendidik dan dialogis; (2) memahami model-model pembelajaran yang mendukung terlaksananya pendidikan vokasional; (3) menyusun rencana pelaksanaan pembelajaran; (4) memiliki pemahaman wawasan atau landasan kependidikan vokasional; (5) memahami karakteristik peserta didik; (6) menyusun instrumen penilaian yang beragam dan kontekstual; (7) menyediakan media pembelajaran terkait mata pelajaran yang konstekstual; memanfaatkan TIK untuk kepentingan pembelajaran; dan (9) menyampaikan materi pelajaran secara spesifik terkait ketepatan informasi yang diberikan.

Kendala-kendala dalam pengembangan/ pengimplementasian kompetensi pedagogik bagi guru vokasional meliputi: (1) kurang pemaham-an tentang landasan/filosofi pendidikan vokasi-onal; (2) kurang pemahaman tentang karakteris-tik siswa dan penggunaan TIK; (3) pergantian kurikulum yang berimplikasi pada berubahnya susunan/format RPP; (4) kurangnya pemahaman mengenai model, metode, strategi, teknik pembelajaran; (5) kurangnya pemahaman me-ngenai metode/jenis penilaian dan media pembelajaran; (6) media pembelajaran terbatas dan kurang update dengan perkembangan yang ada; (7) kurangnya sarpras, diklat, pedoman, waktu; (8) terbebani tugas tambahan; (9) materi tidak match dan kurang update. Sedangkan kendala utama pembelajaran di prodi PTE untuk pengembangan kompetensi pedagogik bagi para calon guru adalah belum terintegrasinya penanaman kompetensi pedagogik dalam pembelajaran. Kompetensi pedagogik dalam proses pembelajaran diperkuliahan masih sebatas pemberian ilmu, tetapi belum ada legalitas kurikulum yang mewadahi penerapan-nya dalam pembelajaran.

Berdasarkan kendala-kendala tersebut, upaya-upaya yang dapat dilakukan guru dalam pengembangan kompetensi pedagogik adalah mengikuti diklat dan belajar mandiri. Lebih lanjut, menurut responden guru wawasan kompetensi pedagogik oleh guru vokasional sebagian besar diperoleh saat guru sudah bekerja. Hal ini menunjukkan bahwa proses pembelajaran perkuliahan belum cukup membekali para calon guru untuk memperoleh pemahaman dan penguasaan akan kompetensi pedagogik. Untuk mengatasi hal tersebut, upaya pengembangan kompetensi pedagogik bagi calon guru yang dapat dilakukan selama perkuliahan diantaranya adalah: (1) pembuatan modul pembelajaran praktikum dan teori yang memuat kompetensi untuk menjadi calon guru; (2) perkuliahan di prodi Pendidikan Teknik Elektronika (S1) bagi calon guru dilaksanakan dengan mengintegrasikan kompetensi pedagogikpada proses pembelajaran, sehingga teknik pengajarannya berbeda dengan prodi Teknik Elektronika (D3); (3) memasukan konsep pendidikan vokasional dan 
kemampuan beradaptasi dengan kondisi setiap kelas termasuk perbedaan karakteristik peserta didik; dan (4) pemberian contoh oleh dosen berupa penerapan kompetensi pedagogik (juga dilakukan melalui pembelajaran keelektronikaan tidak hanya pada mata kuliah kependidikan. Sedangkan upaya yang dapat dilakukan dosen untuk mengatasi kendalakendala dalam pembelajaran di prodi PTE untuk menanamkan pemahaman dan penguasaan kompetensi bagi calon guru, adalah: (1) menetapkan aspek kompetensikompetensi ideal guru vokasional TAV pada tujuan pembelajaran; (2) menyusun RPP/ skenario pembelajaran yang memuat unsurunsur membelajarkan kompetensi-kompetensi ideal guru vokasional TAV; (3) peningkatan skill (terkait kompetensi pedagogik) melalui training; dan (4) pembuatan modul pembelajaran yang sudah mengintegrasikan penanaman kompetensi pedagogik.

\section{SIMPULAN}

Peningkatan penguasaan kompetensi pedagogik dapat diperoleh dari pemahaman dan kesadaran mengenai pentingnya penguasaan aspek-aspek kompetensi pedagogik. Berdasarkan hasil penelitian diperoleh sembilan aspek kompetensi pedagogik terpenting. Berbagai kendala pengembangan kompetensi pedagogik yang ditemukan terkait kurangnya wawasan pedagogik, kurangnya sarana dan prasarana, terbebani tugas tambahan dan kurang update penggunaan TIK. Pemerolehan sebagain besar wawasan kompetensi pedagogik guru SMK diperoleh saat bekerja. Hal tersebut menunjukkan bahwa pengembangan kompetensi pedagogik di perkuliahan perlu lebih diupayakan, khususnya untuk materimateri yang berkaitan langsung dengan pembelajaran vokasional abad 21 .

Kendala pengembangan kompetensi ideal bagi guru adalah kurang pemerataan kesempatan untuk mengkuti diklat pengembangan diri, kurangnya kerjasama antar guru; kurangnya sumber-sumber belajar; banyaknya tugas administrasi guru; keterbatasan waktu dan biaya; kurangnya kesadaran diri dan niat; kurang respon guru terhadap perkembangan ilmu sehingga terkesan nyaman dengan kondisi yang dijalani; beban administrasi dan tugas tambahan yang terlalu banyak; keterbatasan sarana prasarana; kurangnya kerjasama dengan DUDI/ dinas pendidikan/ lembaga lain yang terkait;

Upaya untuk mengatasi kendala tersebut adalah memanfaatkan peran dosen sebagai role modelbagi calon guru pada saat perkuliahan yakni sebagai contoh panutan untuk ditiru; dosen harus memberi contoh yang baik sesuai dengan peraturan; selain memberi bekal keilmuan dosen dapat menjadi contoh dalam mengajar sekaligus sebagai inspirator dan motivator sehingga mahasiswa mengetahui cara mengajar yang sesungguhnya yang dapat diterapkan nantinya disekolah.

\section{DAFTAR PUSTAKA}

Claire Rees, et.al. 2007. Student employability profiles: a guide for higher education practitioners. 2nd revised edition. York: The higher Education Academy

Desliana Maulipaksi. 2016. 7 Provinsi rain nilai terbaik uji kompetensi guru 2015. Diambil dari http://www.kemdikbud.go.id/main/blog /2016/01/7-provinsi-raih-nilai-terbaikuji-kompetensi-guru-2015 pada 1 Maret 2016

Djoko Santoso. 2014. Need Assessment pengembangan keprofesionalan berkelanjutan guru SMK Teknik Audio Video. Jurnal Pendidikan Teknologi dan Kejuruan, Vol. 22 No. 22 Oktober 2014 hal 148 - 154

Felix Rauner \& Joachim Dittrich. 2006. Increasing the Profile and Professionalisation of the Education of TVET Teachers and Trainers. Dalam Frank Bünning \& Zhi-Qun Zhao (eds.) 
TVET Teacher Education on the Threshold of Internationalisation, hal 34 - 42. Inwent : Bonn

Fritz Oser, Patrizia Salzmann, \& Sarah Heinzer. 2009. Measuring the competence-quality of vocational teachers: An advocatory approach. Empirical Research in Vocational Education and Training 1 (2009) 65-83

Harry Stolte. 2006. Capacity Building in TVET Staff Development in the Context of International Cooperation. Dalam Frank Bünning \& Zhi-Qun Zhao (eds.) TVET Teacher Education on the Threshold of Internationalisation, hal 25 - 33. Inwent : Bonn

ILO. 2010. Teachers and trainers for the future - Technical and vocational education and training in a changing world. Geneva: International Labour Organization

Joachim Dittrich. 2006. Vocational Disciplines - What could a general framework look like?. Dalam Frank Bünning \& Zhi-Qun Zhao (eds.) TVET Teacher Education on the Threshold of Internationalisation, hal $110-123$. Inwent : Bonn

Margaret Puspitarini. 2014. Kompetensi Pedagogis Guru di Indonesia rendah. Diambil dari http://news.okezone.com/read/2014/11/ 21/65/1068988/kompetensi-pedagogisguru-di-indonesia-rendah pada 1 Maret 2016

McCawley, Paul F. 2009. Methods for Conducting an Educational Needs Assessment: Guidelines for Cooperative Extension System Professionals. Idaho: University of Idaho Extension

P21 Century Learning. 2015. P21 Framework Definitions. Dambil dari dari www.p21.org pada 1 Maret 2016
Peter Gerds \& Zhi-Qun Zhao. 2006. Modular TVET Teacher Training System, Based on Teacher Qualification Standards a Proposal of UNIP. Dalam Frank Bünning \& Zhi-Qun Zhao (eds.) TVET Teacher Education on the Threshold of Internationalisation, hal $125-138$. Inwent: Bonn

Qiding Yu. 2009. Study On Establishing National Standard Of Vocational Teachers' Training In China. Journal of Technical Education and Training, Vol 1 nomor 12009 hal 59-66

Republik Indonesia. 2005. Undang-Undang Republik Indonesia Nomor 14 Tahun 2005 tentang Guru dan Dosen. Jakarta.

Republik Indonesia. 2007. Lampiran Permendiknas No. 16 Tahun 2007 tentang Standar Kualifikasi Akademik dan Kompetensi Guru. Jakarta

Republik Indonesia. 2008. PP RI No. 74 tahun 2008 tentang Guru. Jakarta

Republik Indonesia. 2009. Permenpanrb No. 16 Tahun 2009 tentang Jabatan Fungsional Guru dan Angka Kreditnya. Jakarta

Republik Indonesia. 2009. Peraturan Menteri Pendidikan Nasional No. 28 Tahun 2009 tentang Standar Kompetensi Kejuruan SMK/MAK. Jakarta.

Republik Indonesia. 2010. Peraturan bersama Mendiknas dan Kepala BKN No. 03/V/PB/2010 dan No. 14 Tahun 2010 tentang Petunjuk Pelaksanaan Jabatan Fungsional Guru dan Angka Kreditnya. Jakarta

Republik Indonesia. 2010. Permendiknas No. 35 Tahun 2010 tentang Petunjuk Teknis Pelaksanaan Jabatan Fungsional Guru dan Angka Kreditnya. Jakarta

Wardiman D. (1998). Pengembangan sumberdaya manusia :Melalui Sekolah Menengah Kejuruan(SMK).Jakarta: PT. Jayakarta Agung Offset. 